\title{
Corporate Social Responsibility and Financial Performance: The Case of ASEAN Telecommunications Companies
}

\author{
Fathyah Hashim¹, Essia Ahmad Ries ${ }^{1}$, and Ng Teck Huai ${ }^{1,2}$ \\ ${ }^{1}$ Graduate School of Business, Universiti Sains Malaysia, 11800 USM, Penang, Malaysia \\ ${ }^{2}$ Dorf Ketal Chemicals Pte. Ltd., Singapore
}

\section{Abstract}

This paper examines the relationship between corporate social responsibility and financial performance in ASEAN (The Association of Southeast Asian Nations (ASEAN) is a regional intergovernmental organization comprising ten countries in Southeast Asia, which promotes intergovernmental cooperation and facilitates economic, political, security, military, educational, and sociocultural integration among its members and other countries in Asia) telecommunications companies. Corporate social responsibility (CSR) dimensions assessed in this study include community, corporate governance,

Corresponding Author:

Fathyah Hashim

fathashim@usm.my

Received: 5 August 2019 Accepted: 14 August 2019 Published: 18 August 2019

Publishing services provided by Knowledge

(c) Fathyah Hashim et al. This article is distributed under the terms of the Creative Commons

Attribution License, which

permits unrestricted use and

redistribution provided that the

original author and source are credited.

Selection and Peer-review under the responsibility of the FGIC2019 Conference Committee. employee relations, and the environment. Meanwhile, financial performance is obtained by analysing the organisation's return on assets (ROA). Although there have been past studies, investigate the relationship between CSR and Financial Performance (FP), cross-country, and through structural equation modeling, there is still a lack of data focusing in ASEAN telecommunications industry. Therefore, using 17 telecommunications companies in ASEAN countries based on their five years' annual reports (2013-2017), this study attempt to provide empirical evidence on the possible relationship between CSR and FP. However, this study found no significant relationship between the two. This study provides a more in-depth understanding theoretically and practically on corporate social responsibility on financial performance in ASEAN telecommunications industry.

Keywords: corporate social responsibility, financial performance, ASEAN

\section{Introduction}

CSR has fascinated an abundance of thought over the past decade. Recently, in this changing global economic environment, numerous companies have increasingly participated in relentless efforts to characterize and incorporate CSR into all traits of their businesses. In today's economic landscape, the corporate board of directors has received enormous demands from stakeholders to bestow resources to fulfill social responsibility. The concept is precisely bred by a handful of ethical conscious NGOs, the 
union of labours, activists and encouraged stakeholders such as employees, suppliers, customers, communities, governments, and even stockholders to deliver pressure to the corporation (Zu \& Song, 2009; Grayson \& Hodges, 2017; Quazi \& Richardson, 2012). CSR is believed to be a phenomenon varied across different cultures; people from different part of the world may carry different perceptions and expectations towards CSR (Crane, Matten, \& Spence, 2019). In western countries, CSR has been a central awareness when business activity is being carried out. However, in Asian countries, especially in the ASEAN region, CSR is in a relatively lower perception in both at corporate and state levels (Waworuntu, Wantah, \& Rusmanto, 2014; Visser, \& Tolhurst, 2017). As most of the past studies on CSR were conducted in the context of western economies, there is none as of known is discussing CSR in the post-colonial, small and emerging developing state (Jamali, Karam, Yin, \& Soundararajan, 2017; Belal, 2011). Thus, there is a need to investigate CSR in developing countries, as it will serve as an invaluable insight into how the growing economies are reacting towards the rising demand for CSR in their business conduct.

The growth of CSR in ASEAN region is traceable through the entry of multinational corporation (MNC) into the area as it marks the beginning of liberation and globalisation where the stakeholders are demanding higher expectation towards business organisations (Giri, \& Anjanappa, 2017). In this study, CSR was targeted to have more reachability to most of the corporate stakeholders in where telecommunications sector appeared to be involved in almost everybody in the targeted group as in the last 20 years; mobile phones have emerged from an expensive device to easily affordable and accessible. In addition, the ASEAN member countries government has launched initiatives to develop info-structure to harness economy advantage (Wang, 2016). To satisfy consumer needs in the region, internet calling has slowly replaced the traditional calls especially with the introduction of messenger services and drew many customers in the place. Some developing markets in ASEAN such as Indonesia and the Philippines particularly have directly moved into mobile technology territory and bypassed the fixed telephony line to improve market penetration with increasing consumer demand (Graham, 2018). Although there have been past studies, investigate the relationship between CSR and Financial Performance (FP), cross-country, and through structural equation modeling, there is still lack of data focusing in ASEAN telecommunications industry (Lee, Cin, \& Lee, 2016; Hou, 2018). ASEAN telecommunications is one of the fastest-growing among other regions due to lower cost of ownership and government initiatives to connect everyone (Roca, 2018). As going into the era of digitalisation, the increasing number of subscribers could play an essential factor in CSR, and financial performance as more are expected to 
be benefitted especially in developing country region such as ASEAN (Fuzi, Habidin, \& Ong, 2018; Jensen, 2001). Therefore, this research serves as a study to close the gap in CSR impact towards FP to enhance the lack of literature on ASEAN telecommunications industry. In addition, this study serves as an attempt to help managers in the ASEAN telecommunications industry to fulfill their social responsibility part and concerned. It will help the manager to decide if there is any adverse effect on the financial performance when the company is engaged in CSR activity. Correspondingly, this study contributes to further development of theoretical knowledge in corporate social responsibility and financial performance. It is also striving to provide concrete contribution which can help to strengthen organisational performance.

\section{Literature Review}

This section offers a review of preceding literature that has been shown on relevant topics such as corporate social responsibility and financial performance. It is then trailed by an analysis of the essential theories to underpin the theoretical framework and research hypotheses which has been developed and tested accordingly.

\subsection{Corporate Social Responsibility (CSR)}

CSR is an equivocal concept that can be explained in several ways which offer differing views concerning the social role of the corporation (Clarkson, 1995). The dispute is often relative to stakeholder-shareholder theories where corporate should focus on increasing shareholders' wealth through corporate instruments (Wilcke, 2004; Jensen, 2001); or through fulfilling various stakeholders' requirement, it will generate greater business returns (Castelo \& Lima, 2007; Freeman, 2010). Kinder, Lydenberg, of Domini, Inc (KLD) is an independent rating firm that appraises the benchmark the social responsibility of a firm and they had developed a reputable index called KLD index named after the firm and was widely used by CSR studies of other scholars. KLD index judges by measuring the CSR dimensions and a decisive factor through quantitative analysis on the mentioned criteria (Waddock \& Graves, 1997). The KLD performance index is measured on a basis which is conducted using content analysis method to collect the data with relevant to CSR dimensions which aligns with this study including community, corporate governance, employee relations, and environmental sustainability. There were another four dimensions in KLD which is not suitable in the context of this study 
and hence excluded namely human rights, diversity, product safety and controversial business issues (Lim, 2011).

\subsubsection{Community}

CSR in community effort is an ordinary course of activities and programs, strategies formulation, and process to develop community sustainability as a base when marketing the potential growth of locally intensive effort to promote economy return. The comprehensive attempt to community development is seen as a real way of corporate to build the social foundation in the civilian population. Community development may be explained as a progression of stimulating the unwelcomed and objectionable discrepancy of a scenario where the quality of community can be deteriorated with corporate growth without good CSR practices. It will enhance the sense of community cohesion where all levels of society and citizen are drawn (Haugh, 2012).

\subsubsection{Corporate Governance}

CSR is seen as necessary to the estrangement of ownership and control when principalagent conflict is discussed according to Ingley (2008) which a handful of scholars has supported the same view (Mahoney \& Thorne, 2005, Elkington, 2006, Kakabadse, 2007, Mackenzie, 2007, Jamali et al., 2008). These studies suggested that the board's agenda always included CSR priority and they intended to accomplish it with the support of the board majority.

Indeed, Jamali et al. (2008) observed that managers and directors have targets and purposes of fulfilling CSR agendas along with good driving factor from the core leader of the organisation. Hung (2001) mentioned the role of board management is contemplated as the decision-maker party which generates a wide range of contributed activity with the intention that brings good to the society and aligns with corporate social interest in CSR reputation. An extensive amount of evidence also exists supporting the positive correlation of corporate governance assignment to CSR (Johnson \& Greening, 1999; McKendall et al., 1999; Webb, 2004; Dunn \& Sainty, 2009; Huang, 2010).

\subsubsection{Employee Relations}

A myriad of the analysis revealed that the employee stakeholders could be affected by corporate schemes and tactics, it can be segregated that firm's corporate atmosphere 
and working environment are linked to activities and tasks assigned especially with those aiming to achieve higher societal goals for greater CSR endeavour. Matten and Moon (2008) categorised the activities with theories proceeding through implicit and explicit CSR. Implicit CSR is implanted in the patterns, ethics, and governs of a society and its anticipations for firms as a whole. Hence, it is often manifested in a company's workplace atmosphere, including its conventional human resource systems and its performance management accordance. Therefore, there is a sizeable commonality between employees' work-related experiences and the concept of implicit CSR. Explicit CSR embroils prudence decisions made by firms that answer to precise collective interests to potential gains in business and social perspective. Included in decisions may involve programs for instance donations to the charitable organisation, community services, environmental preservation, volunteerism program, establishing safe work and good co-work space and practising good code of human resource conduct (Ellen, Webb, \& Mohr, 2006). Explicit CSR is parallel with CSR literature that advocates corporates held the ultimate responsibility to society beyond legal compliance and monetary attentiveness should practice behaviours that benefit the employee as part of the stakeholders. (Carroll, 1979; Wartick \& Cochran, 1985; Wood, 1991).

\subsubsection{Environment}

Environmental issues and sustainability are gaining in importance in corporate social responsibility commitment. In the last decade, the environmental threat is only under scrutiny by the public for high-risk sectors such as oil and gas industry, mining and automotive manufacturers, and today it was seen to be applied to every industry with increasing ecological awareness (Montiel, 2008). In 1987, World Commission on Environment and Development initially termed environment sustainability in CSR as advancement that come across "the needs of the present without compromising the ability of future generations to meet their own need" and firms should recognise how corporate sustainability is composed in this environment context and inject sustainable development as one of the core values throughout every level in the organisations in every business decision being made (Eweje, 2015).

\subsection{Financial Performance (FP)}

Financial performance is frequently illustrated as a positive representation of business and economic success of a corporate. It is a complex measurement which will be 
affected by several financial activities as such economy landscape, audit and accounting standard and even marketing a new product or territory. As a whole, business performance is often measured through financial and non-financial perspective, and most scholars attempted to measure business performance through both standpoints (Prieto \& Revilla, 2006). Financial performance when used to measure in an organisation is ambiguous as it will be easily impacted by other factors, hence quantitative approach as such return of assets (ROA), business revenues, profitability when compared to other similar industry, cost of goods sold and some several parameters being used by Prieto and Revilla (2006) along with customer and employee satisfaction, product quality and service reputability are assessed for non-financial perspective. Likewise, Solakoglu and Demir (2016) conducted their analysis by using ROA and Return of Equity (ROE) as parameters to determine the financial position of the firm is selected. In a nutshell, financial performance is widely used with ROA as an indicator, and hence, it was selected in this study to assess the business performance of the firm.

\subsection{Relationship between Corporate Social Responsibility and Financial Performance}

The traditional perspective of CSR, when perceived to the corporate governance and management, implies it will incur additional expenses and affect financial performance. This conventional view justified "competitive disadvantage" and eventually leading to deteriorating profitability when corporate conducted CSR (Alexander \& Buchholz, 1978). On the contrary, Freeman (1991) proposed stakeholder theory to oppose the CSR-FP relationship as he believed that the stakeholder group could dictate the company's future and affect economic return if the corporation is deemed not socially responsible. Therefore, CSR is necessary for warranting the business sustainability and potentially directed to enhanced financial performance (Aver \& Cadez, 2009). For instance, satisfied employees will dedicate more to corporate function and improving performance. Meanwhile, customers will make more purchase; satisfied suppliers will provide an extra discount in this context. The main findings of prior literature to support empirical relationship are summarised in Table 1.

\subsection{ASEAN Telecommunications Industry}

ASEAN consumers in the telecommunications landscape have been shifted towards online content including shopping, entertainment, and pay services including the related 
TABLE 1: CSR- FP Relationship in Prior Literature.

$\begin{array}{ll}\text { CSR-FP Relationship } & \text { Prior Literature Support } \\ \text { Positive } & \begin{array}{l}\text { McWilliams and Seigel (2000); Simpson and Kohrer (2002); Mahoney and } \\ \text { Roberts (2007); Burnett and Hansen (2008); Erhemjamts et al. (2013); } \\ \text { Rodgers et al. (2013) }\end{array} \\ \begin{array}{l}\text { Negative } \\ \text { No relationship }\end{array} & \begin{array}{l}\text { Alexander and Buchholz (1978); McWilliams and Siegel (2000); Sun et al. } \\ \text { (2010); Soana (2011) }\end{array}\end{array}$

Source: Authors' own work

governmental transaction. Mobile penetration has grown as subscribers are commonly engaged in more than one mode of communication platform with the blooming accessibility and number of features offered which surpassed developed markets in term of growth annually (Rajan \& Sen, 2002). Most of the government in ASEAN member countries have warranted telecom operators with exclusive operational licenses and implemented protectionist policies and given a chance to monopolise the market. Nonetheless, with increasing contest entering the scenario, their market position has been tremendously challenged. For instance, in Indonesia, Telkomsel, Indosat Ooredoo, and $\mathrm{XL}$ Axiata, which accounted for 80 percent of overall market stake immensely compete. This inter competition is altering the profitability of ASEAN telco, where conventional business approach aimed at assuring progression through aggressive price war is no longer working. In the more developed market such as Singapore, Singtel struggles with competition from over-the-top (OTT) offshore players such as Facebook and Whatsapp, which made an entry to split their market share. Whatsapp has integrated new e-finance business which trying to draw more consumers away from traditional telecom services (Hukill, 2018).

\subsection{Control Variables}

Adding a control variable limits the potential of drawing opposite conclusions regarding the effect of testing the main variables on dependent variables. Therefore, as mentioned by Brooks (2014), firm size as a control variable is important to be tested in the model because it may have a significant effect on the dependent variable. Thus, in this study, firm size and leverage are selected as control variables in this study (Ang, Cole, \& Lin, 2000; Bhagat \& Black, 2001).

Siregar and Bachtiar (2010) examined the impact of the size of firm, profitability, and leverage on the level of corporate social responsibility reporting. The study analysed annual reports by using content analysis method and multiple regressions to examine 
the hypotheses. The finding predicted that the firm size had a positive effect on CSR. Moreover, the findings revealed that leverage and profitability did not have a significant influence on CSR reporting. In the same vein, Ferrier, Smith, and Grimm (1999) show the importance of firm size as a control variable to measure market share; in that, as they explained, the firm size has its effect on the market share. However, using a control variable in the analysis is important because it may have an effect on results (Guest, 2009). Leverage is the ability of the firm to maximise the profit through debt, and it is termed as the ratio of debt over equity in financial analysis. Companies with high leverage if unable to repay the interest, is on the verge of bankruptcy in this context and will be facing the potential of bought over and losing the business owner. Wieland and Flavel (2015) stated with debt financing, most companies can achieve higher ROE and tend to give a good impression to investors and it is seen as a double-edged sword if managed well. As borrowing leverage is eligible for tax advantages, shareholder wealth can be improved potentially.

\section{Underlying Theories}

There are several approaches used by prior researchers to correlate with CSR theories, and some are conflicting, and there was never one perfect criterion to fix every scenario (Chand, 2006). Hence, the two arguments identified to support CSR-FP relationship are Ethical Theory and Shareholder-Stakeholder Theory.

\subsection{Ethical Theory}

Ethical theory suitable to be used in explaining enhanced business relationships and community ties, namely, and generally consisting of the common good approach, the normative stakeholder approach and the universal rights approach. A business is termed as good when there is no harmfulness and exerting an adverse effect on the community and instead, become a constructive backer towards the society (Garriga \& Mele, 2004). Donaldson and Preston (1995) stated that the first normative stakeholder theory is based on two main ideas where firstly, a stakeholder is a person or group that sensibly has legitimate interest over business conducted by a corporate entity and secondly the importance carries intrinsic value. The second normative stakeholder approach expanded, which suggests that stakeholders, such as customers, employees, business suppliers, shareholders, local and foreign communities have an entitlement on the firm. The universal rights approach has been acknowledged globally as the 
foundation to conduct CSR practices (Cassel, 2001). Human rights were prioritised as the leading company societal responsibility when considering business practices. Corporation, when doing business should work together in society, social attentive groups or community to contribute to a collective right approach.

\subsection{Shareholder-Stakeholder Theory}

There is always an argument when the stakeholder-shareholder theory is used to describe CSR. In shareholder theory, the only responsibility of managing board is to ensure the highest level of shareholder benefit is maintained, and wealth is created with corporate resources for profit maximisation (Wilcke, 2004). Garriga and Mele (2004) classified three main objectives to maximise share value within the legal and ethical custody of the country is operated. The maximisation of value which is also short term goal profit was identified as the first objective, followed by strategic economic advantage in the long run when conducting business if CSR is held with profit intention. Thirdly, cause-related marketing to protect shareholder benefit by contributing to society to make customers interested if labelled as a good corporate citizen.

Meanwhile, stakeholder theory conveying that CSR is meant for every party which will be affected by any solid business practices including the local community, employees, suppliers, governments are all equally important aside as compared to shareholder theory which put profit and wealth as a top priority (Castelo \& Lima, 2007; Freeman, 2010).

\subsection{Hypotheses Development}

Based on the theoretical framework as developed above, there are two hypotheses developed for the direct effects and moderating effects, respectively. The predictions were built upon the combination of theory, as discussed in the previous section. Prior literature from Mahoney and Roberts (2007), Burnett and Hansen (2008), Erhemjamts et al. (2013) and Rodgers et al. (2013) supported the positive relationship between corporate social responsibility and financial performance. Hence, it can be summarised that corporate social responsibility is correlated positively with financial performance in the firm of ASEAN telcos as below:

H1: Corporate social responsibility is positively influencing financial performance in ASEAN telecommunications industry. 


\section{Research Methodology}

This research was intended with an analytical approach to identify the direct effect between corporate social responsibility and financial performance within ASEAN telecommunications industry. This section discusses the research sampling and population method, data analysis approach and quantitative analysis which was used in this study. As this study will formulate a hypothesis to test the relationship between corporate social responsibility and business performance, the quantitative positivistic approach was chosen. In this study, secondary data research analysis method was selected as it facilitates the quantitative analysis and maintains the independence of the researcher's perspective as only data provided in the annual report will be analysed and the info is widely available for verification for company management and investor which are the primary audience of this paper.

\subsection{Population and Sampling Frame}

In this study, the identified population would be all the public listed telecommunication companies on the equities market of stocks exchange in the ASEAN region as being presented in Table 2. In the context of ASEAN countries, Brunei, Vietnam, Cambodia Myanmar and Laos are not included in the study as they do not fulfill second criteria of having publicly listed telecommunications company in the sampling frame and hence was excluded from the study.

TABLE 2: Sample Size for ASEAN Telecommunications Industry.

\begin{tabular}{|c|c|c|c|}
\hline No. & Country & No. of Telco (N) & Observation (n) \\
\hline 1 & Indonesia & 4 & 20 \\
\hline 2 & Malaysia & 4 & 20 \\
\hline 3 & Thailand & 4 & 20 \\
\hline 4 & Singapore & 3 & 15 \\
\hline \multirow[t]{2}{*}{5} & Philippines & 2 & 10 \\
\hline & Total & 17 & 85 \\
\hline
\end{tabular}

The sampling frame of telecommunications companies must fulfill the following criteria: first, the companies must be listed on the stock exchange markets in ASEAN region such as Bursa Malaysia, SGX (Singapore Exchange), SET (The Stock Exchange of Thailand), PSE (Philippines Stock Exchange), IDX (Indonesia Stock Exchange), HOSE (Ho Chi Minh) Stock Exchange and HNX (Hanoi Stock Exchange) from year 2013 to 
2017. Secondly, the information available or report published must be published in the English language.

\subsection{Measurement of Variables}

On the other hand, content analysis is the most common technique used in previous studies to access corporate social responsibility disclosure (Amran et al., 2008), as the financial reports accompanied will explain how the expenditure of the firm will be used, and in some cases it is encouraged to disclose CSR and sustainability for better corporate image and branding. In this study, dependent variable which is financial performance was identified in this study by analysis Return of Assets (ROA) of the firm to understand the level of CSR involvement in corporate will actually affect the firm business return which has been positively proved by Mahoney and Roberts (2007), Burnett \& Hansen (2008), Erhemjamts et al. (2013) and Rodgers et al. (2013), but firstly for telecommunications industry chosen for ASEAN region. Independent variable identified in this study is Corporate Social Responsibility (CSR) which four dimensions were being chosen in this study according to the KLD index which was proposed by Lim (2011). The other aspects in the KLD index are not suitable in the telecommunications context and hence was not selected in full. An index of " 1 " is indicating sentence characteristic presence and " 0 " indicating sentence characteristic absence will be constructed for each observation through secondary data analysis. Table 3 listed the sentence characteristics when the content analysis is being employed towards the annual report of companies. Firm size and leverage are two of the control variables being identified in this study, and the data are extracted through secondary data analysis from the financial report. Firm size is characterised by a number of employees in the firm and for less than 100,000 will be given as "1" and "0" for the larger firm; similarly, " 1 " will be given for firm with financial leverage ratio more than $10 \%$ and " 0 " vice versa in the data analysis.

\subsection{Data Analysis}

In this study, statistical analysis is done with the assistance of IBM SPSS ${ }^{\circledR}$ Statistics and Smart PLS software for data interpretation. IBM SPSS ${ }^{\circledR}$ Statistics was employed to conduct descriptive analysis to provide a summary of corporate social responsibility in four dimensions of CSR, which has been identified as an independent contributive variable in the KLD index. Frequency, mean, and standard deviations are summarised 
TABLE 3: Corporate Social Responsibility Dimension.

\begin{tabular}{|c|c|}
\hline CSR Dimension & Sentence Characteristics \\
\hline \multirow[t]{6}{*}{ Environment } & Clean Energy/ Energy Saving \\
\hline & Carbon emission reduction \\
\hline & Wastewater re-use \\
\hline & Management Systems \\
\hline & Pollution Prevention/Control \\
\hline & Recycling Program \\
\hline \multirow[t]{5}{*}{ Corporate Governance } & Regulatory Compliance Systems \\
\hline & Operational Transparency \\
\hline & Respect for Shareholder Rights \\
\hline & Implement Informational Transparency \\
\hline & Social and Environment Performance Measure \\
\hline \multirow[t]{11}{*}{ Employee Relations } & Employee Health and Safety \\
\hline & Physical Health \\
\hline & Mental Health \\
\hline & Retention Programs \\
\hline & Establishment of Safety Department/ Committee/ Policy \\
\hline & Compliance to OSHA Act \\
\hline & Receiving Health and Safety Award \\
\hline & Employee Involvement in Decision Making \\
\hline & Providing Healthcare for Employee \\
\hline & $\begin{array}{l}\text { Learning and development program/training employees through } \\
\text { in-house/e-learning programs }\end{array}$ \\
\hline & $\begin{array}{l}\text { Giving financial assistance to employees in educational institutions; } \\
\text { continuing education courses }\end{array}$ \\
\hline \multirow[t]{6}{*}{ Community } & Support for School, Education \\
\hline & Volunteer Programs \\
\hline & Charitable giving to charitable organizations \\
\hline & $\begin{array}{l}\text { Industry associations sponsor community health moreover, green space } \\
\text { preservation programs }\end{array}$ \\
\hline & Sponsors public artists and conferences \\
\hline & Public welfare \\
\hline
\end{tabular}

respectively for each aspect in the community, corporate governance, employee relations and community. Hypothesis testing with the usage of Smart PLS was used to test the direct effect of CSR of financial performance and also the moderating influence of a number of subscribers in this context. Bootstrapping approach function was used in the software to conduct one-tailed t-test at $5 \%$ significance level to examine the path coefficients. There is one independent variable, corporate social responsibility with four 
sub-dimension and it is expected to have a positive effect on the financial performance of ASEAN telecommunications company.

\section{Findings}

After the data has been acquired by content analysis of the annual financial report by ASEAN telcos, IBM ${ }^{\circledR}$ SPSS software was used to conduct descriptive statistics to summarise the variable to show the mean and standard deviation for analytics.

\subsection{Descriptive Analysis}

In Table 4, the independent variable is corporate social responsibility dimensions of environment, corporate governance, employee relations and community which had their minimum and maximum indicating a number of times sentence characteristics appeared during data collection. Meanwhile, controlled variable leverage is calculated as the ratio of total liabilities over shareholders' equity and had a minimum of 0.14 and maximum of 21.37 and a mean of 2.74 times among the 85 financial results, and firm size had a minimum of 1551 and maximum of 27000 . The dependent variable in the study is a financial performance which characterised in Return of Assets (ROA), and the minimum is $-9 \%$ which indicated a net loss and maximum of $47 \%$ and a mean of $10 \%$ among all the sample sets. Lastly, the moderating variable of number subscribers has a minimum of 1.49 million and a maximum of 318.3 million and a mean of 46.5 million subscribers.

TABLE 4: Descriptive Statistics ( $\mathrm{N}=85$ ).

\begin{tabular}{|l|c|c|c|c|}
\hline & Minimum & Maximum & Mean & Std. Deviation \\
\hline Environment & 0.00 & 5.00 & 0.51 & 0.50 \\
\hline Corporate Governance & 0.00 & 4.00 & 1.88 & 1.17 \\
\hline Employee Relations & 0.00 & 5.00 & 2.45 & 1.23 \\
\hline Community & 0.00 & 6.00 & 3.47 & 1.35 \\
\hline Leverage & 0.14 & 21.37 & 2.74 & 3.04 \\
\hline Firm Size & 1551.00 & 27000.00 & 8997.40 & 8679.75 \\
\hline ROA & -0.09 & 0.47 & 0.10 & 0.11 \\
\hline Number of Subscribers & 1.49 & 318.30 & 46.50 & 62.61 \\
\hline Source: Authors' own work & & & & \\
\hline
\end{tabular}




\subsection{Measurement Model Evaluation}

The theoretical framework was constructed in Smart PLS with variable and structural links to test on the representativeness of the model of the construct in this study. PLS algorithm was applied with a maximum of 300 iterations through the path weighting scheme to verify the model's validity and reliability, as shown in Figure 1.

After the PLS model being applied, an R-squared $\left(R^{2}\right)$ value is attained to identify the variation of the model-dependent variable which can be explained by independent variable effect and according to Cohen (1992), $\mathrm{R}^{2}$ of more than 0.26 is widely accepted as substantial, while less than 0.02 is weak and in between can be term as moderate effect.

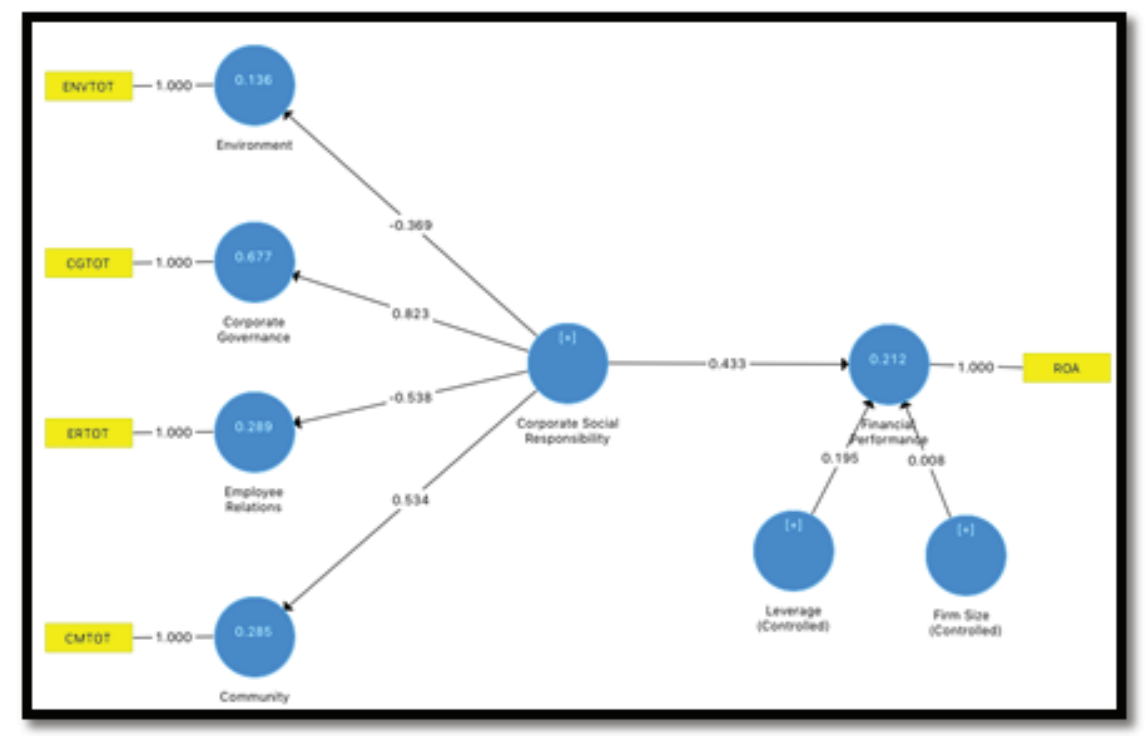

Figure 1: Direct Effect (PLS Algorithm Applied) (Source: Authors' own work).

From Figure 1, Corporate Social Responsibility and Financial Performance have a favorable path coefficient of 0.54 , indicating the independent variable identified affects the dependent variable. Also, $\mathrm{R}^{2}$ value is detected to be 0.225 , indicating $22.5 \%$ of the variation in financial performance can be explained by corporate social responsibility in this model, and the model fitness is substantial.

In one-tailed T-test for hypothesis testing, the T-value must be higher than 1.645 to be statistically significant at 0.05 level of significance. The results after bootstrapping applied are tabulated in Table 5 below.

Hypothesis $\mathrm{H} 1$ predicts that corporate social responsibility is positively influencing financial performance in ASEAN telecommunications industry. The analysis result showed that $\mathrm{H} 1$ is not supported, although it is positively related. Hence, it is said 
TABLE 5: Path Coefficient and Hypothesis Testing (Direct Effect).

\begin{tabular}{l|l|c|c|c|} 
Hypothesis & Path & $\begin{array}{c}\text { Path } \\
\text { Coefficient }\end{array}$ & $\begin{array}{c}\text { T-Values } \\
\text { (1-tailed) }\end{array}$ & Results \\
\hline H1 & $\begin{array}{l}\text { Corporate Social Responsibility } \\
\rightarrow \text { Financial Performance }\end{array}$ & 0.433 & 1.106 & $\begin{array}{c}\text { H1 is not } \\
\text { supported }\end{array}$ \\
\hline Source: Authors' own work & & &
\end{tabular}

that economic performance in ASEAN telecommunications industry is not positively influenced by corporate social responsibility.

\section{Discussion of Findings}

This objective of this research is to identify if there is a positive relationship in between corporate social responsibility and financial performance in ASEAN telecommunications industry to fill the gap of the study in this area of research. The hypothesis constructed earlier was tested with bootstrapping, and one-tailed T-test has rejected the relationship.

$\mathrm{H}_{1}$, which predicted corporate social responsibility is positively influencing financial performance in ASEAN telecommunications industry. However, the hypothesis was not supported through bootstrapping analysis, which indicates that the CSR is not affecting the financial performance of the company. In ethical theory as suggested by Garriga and Mele (2004), the companies which conducted CSR can be through common good, normative stakeholder and universal rights approach.

In ASEAN telecommunications industry, it was found that most of the CSR activities are done in community dimension compared to the other three dimensions, namely environment, employee relations, and corporate governance. This observation supported the normative stakeholder approach of ethical theory, where the telecommunications company actually behave ethically in business conducts to ensure the community, all stakeholders include customers, suppliers, employees are having intrinsic values and companies have the responsibility to preserve their human rights in giving back to the community.

However, in shareholder-stakeholder theories, the only responsibility of the managing director is to ensure the shareholder wealth is well taken care of, with maximum profitability through corporate resources. In this way, the CSR activities being conducted in the company is seen as a tool to improve the image of the corporate and with the intention to boost benefits, while not sincerely done as what mentioned as a common good approach in ethical theory. Also, it might be also due to the legal regulations that certain percentage of earnings or corporate should comply CSR activities to get tax 
rebates which made the companies conduct CSR despite the management knowing that CSR will impact the profitability of the company. In order to protect shareholder benefit, they are forced to become a good corporate citizen.

The outcome of the hypothesis testing is consistent with the view of several scholars in a similar area of study. McWilliams and Siegel (2001) have found a neutral relationship in the CSR and FP relationship by regressing the effect of CSR and financial performance through their studies. Sun et al. (2010) used corporate governance and environmental dimensions to assess the relationship with earnings and also find no statistical association in the measurement and concluded the neutral relationship. Soana (2011) measured the ethical rating of the American banking sector to examine the proxies of CSR that correlate the corporate financial performance and also supported with no significant link.

However, according to Friedman (2010), if the firm does not conduct CSR activities because of profit concern, then it is said to be socially irresponsible. There are still many managers willing to conduct CSR base on ethical theory, even if opposed by shareholder theory. Mackey et al. (2007) stated, shareholder, can comply with ethical responsibility and conduct CSR if they can find a way that reduces this expense and not impacting firm financial performance. Hence, this study is giving an insight of the management of ASEAN telco that despite the negative impact of CSR on financial performance, it can be managed if CSR cost is optimized before they decide whether to conduct the activity at their social responsibility.

\section{Conclusion}

The influence of CSR on financial performance has always been a top concern of the managers, and this study will help when they are deciding to conduct CSR. Since there is no empirical relationship that defines this relationship well, this study adds to the existing literature in the telecommunications industry, as it seems that the magnitude of CSR is larger among other sectors. Upon all, this will help to characterise the relationship in developing nations, especially in the ASEAN region.

This study will help the government to determine whether the companies are willing to allocate their costs toward CSR. Moreover, this study emphasizes the level of activities through CSR in ASEAN companies. Thus, this study helps the government in ASEAN to focus on the level of social activities through CSR as an important matter. This study will be useful to the companies that will consider and identify the corporate governance 
characteristics that will enhance the level of CSR. Thus, the result of the study has some implications on the government, public listed companies, and the regulatory bodies.

As this study was done through content analysis which gives flexibility for a researcher, it will be limited if there are non-disclosure CSR items in a financial report published and affects the impression management when evaluating the corporate social responsibility dimension. As there is no empirical relationship exactly decided thus far, CSR and financial performance is the case on a case basis, and it requires a significant amount of research that consistently found similar relationship to be more accurate. Perhaps a more comprehensive analysis could demonstrate how different governance characteristics interact in analysing the level of CSR in the ASEAN context.

This study serves as the first exposure to corporate social responsibility and financial performance studies in the ASEAN region, which can be done for more industries in the region. Future study can consider investigating other variables such as level of technology employed, number of devices held by subscribers.

In conclusion, this study found that there is no relationship between corporate social responsibility and financial performance in ASEAN telecommunications industry. Managers of the telecommunications companies of ASEAN or other industry can take note of this relationship and discuss the ways to conduct CSR at ethical responsibility or at optimization to ensure that shareholders benefit also well protected. This study extended the CSR field in the developing nation region and added to the limited studies, especially in the telecommunications industry and ASEAN region, which can be further explored in another context.

\section{References}

[1] Alexander, G. J., \& Buchholz, R. A. (1978). Corporate social responsibility and stock market performance. Academy of Management journal, 21(3), 479-486.

[2] Amran, A. \& Selvaraj, S. D. (2008). The impact of government foreign affiliate influence on corporate social reporting: The case of Malaysia. Managerial Auditing Journal, 23(4), 386-404

[3] Ang, J. S., Cole, R. A., \& Lin, J. W. (2000). Agency costs and ownership structure. the Journal of Finance, 55(1), 81-106.

[4] Aver, B., \& Cadez, S. (2009). Management accountants' participation in strategic management processes: a cross-industry comparison. Journal for East European Management Studies, 310-322. 
[5] Baird, P. L., Geylani, P. C., \& Roberts, J. A. (2012). Corporate social and financial performance re-examined: Industry effects in a linear mixed model analysis. Journal of Business Ethics, 109, 367-388. doi:10.1007/s10551-011-1135-z

[6] Belal, A. R. (2011). A study of corporate social disclosures in Bangladesh. Managerial Auditing Journal, 16(5), 274-289.

[7] Bhagat, S., \& Black, B. (2001). Non-Correlation between Board Independence and Long-Term Firm Performance. Journal of Corporation Law, 27, 231-273.

[8] Burnett, R. D., \& Hansen, D. R. (2008). Eco efficiency: Defining a role for environmental cost management. Accounting, Organizations and Society, 33(6), 551-581.

[9] Brooks, C. (2014). Introductory Econometrics for Finance: Cambridge University Press.

[10] Carroll, A. (1979). A Three-Dimensional Conceptual Model of Corporate Performance. The Academy of Management Review, 4(4), 497. doi: 10.2307/257850

[11] Cassel, D. (2001). Human rights business responsibilities in the global marketplace. Business Ethics Quarterly, 11(2), 261-274.

[12] Castelo, B. M., \& Lima Rodriques, L. (2007). Positioning stakeholder theory within the debate on corporate social responsibility.

[13] Chand, M. (2006). The relationship between corporate social performance and corporate financial performance: Industry type as a boundary condition. The Business Review, Cambridge, 5(9), 240-245.

[14] Clarkson, M. B. E. (1995). A stakeholder framework for analyzing and evaluating corporate social performance. Academy of Management Review, 20, 92-117.

[15] Crane, A., Matten, D., \& Spence, L. (Eds.). (2019). Corporate social responsibility: Readings and cases in a global context. Routledge.

[16] Donaldson, T., \& Preston, L. (1995). The stakeholder theory of the corporation: concepts, evidence, and implications. Academy of Management Review, 20, 6591.

[17] Dunn, P. \& Sainty, B. (2009). The relationship among board of director characteristics, corporate social performance and corporate financial performance. International Journal of Managerial Finance, 5, 407-423.

[18] Elkington, J. (2006). Governance for Sustainability*. Corporate Governance: An International Review, 14, 522-529.

[19] Ellen, P. S., Webb, D. J., \& Mohr, L. A. (2006). Building corporate associations: Consumer attributions for corporate socially responsible programs. Journal of the academy of Marketing Science, 34(2), 147-157. 
[20] Erhemjamts, O., Li, Q., \& Venkateswaran, A. (2013). Corporate social responsibility and its impact on firms' investment policy, organizational structure, and performance. Journal of business ethics, 118(2), 395-412.

[21] Eweje, G. (2015). Emerging Trends in CSR and Sustainability. Business Strategy and The Environment, 24(7), 601-603. doi: 10.1002/bse.1891

[22] Ferrier, W. J., Smith, K. G., \& Grimm, C. M. (1999). The role of competitive action in market share erosion and industry dethronement: A study of industry leaders and challengers. Academy of Management Journal, 42(4), 372-388.

[23] Freeman, R. E., \& Liedtka, J. (1991). Corporate social responsibility: A critical approach. Business Horizons, 34(4), 92-99.

[24] Freeman, R. E. (2010). Strategic management: A stakeholder approach. Cambridge University Press. New York.

[25] Fuzi, N. M., Habidin, N. F., \& Ong, S. Y. Y. (2018). Corporate social responsibility practices in Malaysian automotive suppliers: confirmatory factor analysis. International Journal of Business Excellence, 15(2), 222-238.

[26] Garriga, E., \& Mele, D. (2004). Corporate social responsibility theories: Mapping the territory. Journal Business Ethics, 53, 51-71.

[27] Giri, K., \& Anjanappa, J. (2017). Overview of Sustainability Initiatives by Private Sector in Asia Pacific with a Focus on Timber Product.

[28] Graham, M. (2018). The Future of ASEAN - Time to Act [Ebook] (1st ed., p. 5). Kuala Lumpur: PwC. Retrieved from https://www.pwc.com/gx/en/growth-markets-centre/ assets/pdf/future-of-asean-chapter-7.pdf

[29] Grayson, D., \& Hodges, A. (2017). Corporate social opportunity! Seven steps to make corporate social responsibility work for your business. Routledge.

[30] Guest, P. M. (2009). The impact of board size on firm performance: evidence from the UK. The European Journal of Finance, 15(4), 385-404.

[31] Haugh, H. (2012). Developmental CSR: Corporate social initiatives and community economic development. Academy of Management Proceedings, 2012(1), 10622. doi: 10.5465/ambpp.2012.10622abstract

[32] Hou, T. (2018). The relationship between corporate social responsibility and sustainable financial performance: firm-level evidence from Taiwan. Corporate Social Responsibility and Environmental Management. doi: 10.1002/csr.1647

[33] Huang, C. J. (2010). Corporate governance, corporate social responsibility and corporate performance. Journal of Management \& Organization, 16, 641-655.

[34] Hukill, M. A. (2018). ASEAN telecommunications: Infrastructure, investment and regulatory policies. Asian Journal of Communication, 1(2), 19-40. 
[35] Hung, H. (2011). Directors' Roles in Corporate Social Responsibility: A Stakeholder Perspective. Journal of Business Ethics, 1-18.

[36] Ingley, C. B. (2008). Company growth and Board attitudes to corporate social responsibility. International Journal of Business Governance and Ethics, 4, 17-39.

[37] Jamali, D., Karam, C., Yin, J., \& Soundararajan, V. (2017). CSR logics in developing countries: Translation, adaptation and stalled development. Journal of World Business, 52(3), 343-359.

[38] Jamali, D., Safieddine, A. M. \& Rabbath, M. (2008). Corporate governance and corporate social responsibility synergies and interrelationships. Corporate Governance: An International Review, 16, 443-459.

[39] Jensen, M. C. (2001). Value maximization, stakeholder theory, and the corporate objective function. Journal of applied corporate finance, 14(3), pp. 8-21.

[40] Johnson, R. A. \& Greening, D. W. (1999). The effects of corporate governance and institutional ownership types of corporate social performance. Academy of Management Journal, 42, 564-576.

[41] Kakabadse, A. P. (2007). Being responsible: Boards are reexamining the bottom line. Leadership in Action, 27, 3-6.

[42] Lee, K. H., Cin, B. C., \& Lee, E. Y. (2016). Environmental responsibility and firm performance: the application of an environmental, social and governance model. Business Strategy and the Environment, 25(1), 40-53.

[43] Lim, Y. (2011). Corporate Social Responsibility and Financial Performance in the Taiwan Semi-Conductor Manufacturing Industry. Doctor of Management. University of Maryland University College.

[44] Mackenzie, C. (2007). Boards, Incentives and Corporate Social Responsibility: the case for a change of emphasis. Corporate Governance: An International Review, 15, 935-943.

[45] Mahoney, L. \& Thorne, L. (2005). Corporate social responsibility and Iong-term compensation. Evidence from Canada. Journal of Business Ethics, 57, 241-253.

[46] Mahoney, L., \& Roberts, R. W. (2007). Corporate social performance, and financial performance and institutional ownership in Canadian firms. Accounting Forum, 31, 233-253.

[47] Matten, B. \& Moon J. (2008) 'Implicit' and 'Explicit' CSR: A Conceptual Framework for a Comparative Understanding of Corporate Social Responsibility (2008). Academy of Management Review Vol. 33, No. 2. Available at SSRN: https://ssrn.com/abstract= 978942 
[48] Mckendall, M., Sánchez, C. \& Sicilian, P. (1999). Corporate governance and corporate illegality: The effects of board structure on environmental violations. International Journal of Organizational Analysis, 7, 201-223.

[49] McWilliams, A., \& Siegel, D. (2000). Corporate social responsibility and financial performance: Correlation or misspecification? Strategic Management Journal, 21, 603-609. doi:10.1002/(SICI)1097-0266(200005)21:5<603::AID-SMJ101>3.0.CO;2-3

[50] Montiel, I. (2008). Corporate Social Responsibility and Corporate Sustainability. Organization \& Environment, 21(3), 245-269. doi: 10.1177/1086026608321329

[51] Peng, C. W., \& Yang, M. L. (2014). The effect of corporate social performance on financial performance: The moderating effect of ownership concentration. Journal of Business Ethics, 123, 171-182. doi:10.1007/s10551-013-1809-9

[52] Prieto, I., \& Revilla, E. (2006). Learning capability and business performance: a nonfinancial and financial assessment. The Learning Organization, 13(2), 166-185. doi: 10.1108/09696470610645494

[53] Quazi, A., \& Richardson, A. (2012). Sources of variation in linking corporate social responsibility and financial performance. Social Responsibility Journal, 8(2), 242256. doi: $10.1108 / 17471111211234860$

[54] Roca, E. D. (2018). Price Interdependence Among Equity Markets in the Asia-Pacific Region: Focus on Australia and ASEAN: Focus on Australia and ASEAN. Routledge.

[55] Rodgers, W., Choy, H. L., \& Guiral, A. (2013). Do investors value a firm's commitment to social activities? Journal of business ethics, 114(4), 607-623.

[56] Rajan, R. S., \& Sen, R. (2002). International trade in services in selected ASEAN countries: telecommunications and finance. Institute of Southeast Asian Studies.

[57] Simpson, W. G., \& Kohers, T. (2002). The link between corporate social and financial performance: Evidence from the banking industry. Journal of Business Ethics, 35(2), 97-109.

[58] Siregar, S. V., \& Bachtiar, Y. (2010). Corporate social reporting: Empirical evidence from Indonesia Stock Exchange. International Journal of Islamic and Middle Eastern Finance and Management, 3(3), 241-252.

[59] Solakoglu, M., \& Demir, N. (2016). The role of firm characteristics on the relationship between gender diversity and firm performance. Management Decision, 54(6), 14071419. doi: 10.1108/md-02-2015-0075

[60] Soana, M. G. (2011). The relationship between corporate social performance and corporate financial performance in the banking sector. Journal of Business Ethics, 104, 133-148. doi:10.1007/s10551-011-0894-x 
[61] Subroto, P. H. (2003). A correlational study of corporate social responsibility and financial performance: an empirical survey toward ethical business practices in Indonesia. Unpublished Doctoral Dissertation, Capella University, Minneapolis, Minnesota, USA.

[62] Sun, N., Salama, A., Hussainey, K., \& Habbash, M. (2010). Corporate environmental disclosure, corporate governance and earning management. Managerial Auditing Journal, 25, 679-700. doi:10.1108/02686901011061351

[63] Srinuan, C., Rohman, I. K., Srinuan, P., \& Bohlin, E. (2017). Digital divide in ASEAN countries: explaining the gap. dalam P. Gugler dan J. Chaisse (eds.), 153-162.

[64] Visser, W., \& Tolhurst, N. (2017). The world guide to CSR: A country-by-country analysis of corporate sustainability and responsibility. Routledge.

[65] Waddock, S. A., \& Graves, S. B. (1997). The corporate social performance-financial performance link. Strategic Management Journal, 18(4), 303-319.

[66] Wang, Y. (2016). Offensive for defensive: the belt and road initiative and China's new grand strategy. The Pacific Review, 29(3), 455-463.

[67] Wen, Y., Rwegasira, K., \& Bilderbeek, J. (2002). Corporate governance and capital structure decisions of the Chinese listed firms. Corporate Governance: An International Review, 10, 75-83.

[68] Waworuntu, S. R., Wantah, M. D., \& Rusmanto, T. (2014). CSR and financial performance analysis: evidence from top ASEAN listed companies. Procedia-Social and Behavioral Sciences, 164, 493-500.

[69] Wartick, S., \& Cochran, P. (1985). The Evolution of the Corporate Social Performance Model. The Academy of Management Review, 10(4), 758. doi: 10.2307/258044

[70] Webb, E. (2004). An examination of socially responsible firms' board structure. Journal of Management and Governance, 8, 255-277.

[71] Wilcke, R. W. (2004). An appropriate ethical model for business and a critique of Milton Friedman's thesis. Independent Review-Oakland-, 9(2), pp. 187-210.

[72] Wieland, S., \& Flavel, B. (2015). The relationship between employee orientation, financial performance and leverage. Social Responsibility Journal, 11(4), 716-733. doi: 10.1108/srj-10-2013-0132

[73] Wood, D. (1991). Corporate Social Performance Revisited. The Academy of Management Review, 16(4), 691. doi: 10.2307/258977

[74] Zu, L. \& Song, L. (2009). Determinants of Managerial Values on Corporate Social Responsibility: Evidence from China. Journal of Business Ethics, 88, 105-117. 